\title{
Knowledge, attitudes, and practices towards COVID-19 among Nepalese Residents: A quick online cross-sectional survey
}

\author{
Hussain Asraf', Tripathi Garima², Bishnu Mohan Singh ${ }^{3}$, Ramji Ram ${ }^{4}$, Raman Pal Tripti ${ }^{5}$ \\ ${ }^{1}$ Lecturer, Department of Internal Medicine, National Medical College, Birgunj, Nepal, ${ }^{2,5}$ Lecturer, Department of \\ Community Medicine, National Medical College, Birgunj, Nepal, ${ }^{3}$ Medical officer, Department of Internal Medicine, \\ Hetauda City Hospital, Hetauda, ${ }^{4}$ MBBS student, Third year, National Medical College, Birgunj, Nepal
}

Background: Corona virus disease 2019 (COVID-19) is a highly infectious disease. It is caused by a novel virus belonging to a family known as corona virus. This virus was first identified in the month of December 2019 in Wuhan, China Hubei province. Since its first identification it has spread globally. It was declared a public health emergency of international concern on January 30, 2020 by WHO. Despite all efforts the virus continues to spread and WHO declared it a pandemic on March 11, 2020. In Nepal the first case was tested positive on $23^{\text {rd }}$ January and ever since numbers are increasing as days passed by. Residents of the country are the most important stakeholders to control the spread of such viruses. Nepal is a land locked country situated between India and China and is one of the vulnerable areas among SAARC nations. In spite of being such a vulnerable nation there was a lack of previous studies detecting the degree of awareness among Nepalese residents towards COVID 19. Aims and Objectives: This study aims to assess the current level of awareness towards COVID 19 among Nepalese residents and to analyze their attitudes and practices towards COVID 19 which is very important for people's active participation to control this pandemic. In this study we investigated Nepalese residents KAP towards COVID-19. Material and Methods: This is cross sectional online study. A self-developed online questionnaire was completed by the participants. There were a total 29 questions among which 15 questions assessed knowledge, 6 questions assessed attitude and remaining 8 questions assessed practice. Results: Among the respondents $(n=760), 65.7 \%$ were male,50.3\% were healthcare workers, overall range of correct answers for knowledge questionnaire was $60.0-98.7 \% \%$, that for attitude was $77.9-96.4 \%$ and for practice was 78.2-95.0 \%. Participants with a medical degree had statistically significant better practice against COVID 19 compared with the general population. Conclusion: Findings of this study show that knowledge among people of Nepal about COVID 19 is satisfactory. Yet a significant number of participants are lacking confidence when compared to other countries. Better practice against COVID requires a sense of responsibility, though the respondents with medical background had better sense of act against COVID prevention practice.

Key words: Knowledge; Attitude; Practice; COVID-19; Nepal

\section{Access this article online}

Website:

http://nepjol.info/index.php/AJMS DOI: 10.3126/ajms.v11i3.28485

E-ISSN: 2091-0576 P-ISSN: 2467-9100

Copyright (c) 2020 Asian Journal of Medical Sciences

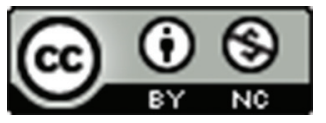

This work is licensed under a Creative Commons Attribution-NonCommercial 4.0 International License.

\section{INTRODUCTION}

COVID 19 is an abbreviation for Corona virus disease 2019 which is an infectious disease caused by a novel virus belonging to the virus family known as Corona virus. It was first identified in December 2019 in Wuhan, the capital of China's Hubei province, and has since spread globally, resulting in the ongoing 2019-20 Corona virus pandemic.The COVID-19 patients can present with symptoms that varies from asymptomatic or paucisymptomatic forms to clinical conditions that are characterized by respiratory failure and patients may need mechanical ventilation and support in an intensive care unit (ICU). Patients may develop multiorgan and 
systemic manifestations in terms of sepsis, septic shock, and multiple organ dysfunction syndromes. In one of the first reports on the disease, presenting patients suffered from fever, malaise, dry cough, and dyspnea. Chest computerized tomography (CT) scans showed pneumonia with abnormal findings in all cases. About a third of patients required ICU care, and mortality among the patients was $15 \% .{ }^{1}$ Another study showed that $81 \%$ of cases had mild disease. Among the cases 14\% developed severe disease. A small fraction of the cases, overall 5\% developed critical disease. ${ }^{2}$ Corona virus also causes diseases like Severe Acute Respiratory Syndrome(SARS) and Middle East Respiratory Syndrome(MERS). However Empirical clinical data have shown that the overall case fatality rate of COVID-19 is $2.3 \%$ in China, much lower than those of SARS (9.5\%), MERS (34.4\%), and H7N9 (39.0\%). ${ }^{3}$ In December 2019, there was an outbreak of pneumonia of unknown cause in Wuhan, Hubei province in China, with an epidemiological link to the Huanan Seafood Wholesale Market. World Health Organization (WHO) was notified about the disease on 31 Dec 2019 by the Chinese Health Authorities. On Jan 7, a novel Corona virus was identified by the Center for Disease Control and Prevention (CDC) from the throat swab sample of a patient, and was subsequently named 2019-nCOV by WHO. WHO declared it a public health emergency of international concern on January 30,despite these efforts, the virus continued to spread and WHO declared it as pandemic on 11 March $2020 .{ }^{4}$

According to WHO situation reports from its first outbreak in Wuhan through 14 April 2020, a total of 1844863 laboratory confirmed cases of COVID 19 associated with 117021 death have been reported globally. This disease is also quickly spreading in SAARC countries. Till 14 April, 2020 the no. of laboratory confirmed cases of COVID 19 in different SAARC countries are as follows: India 10363, Pakistan 5716, Bangladesh 803, Sri Lanka 218, Maldives 20, Nepal 16 and Bhutan 5.

In Nepal, the first case of COVID 19 was tested positive by real-time RT-PCR assay on 23 January 2020 . The case is reported to be a 31-year-old male who studies in Wuhan and traveled to Kathmandu from Wuhan. The Nepalese Government evacuated 175 Nepalese citizens from various parts of the Hubei Province on 16 February, 2020 and quarantined at Kharipati, Bhaktapur and on day 16 of quarantine after the test results were negative, they were sent back home. The second case was tested positive on 22 March 2020 (MOHP). The Government of Nepal issued a national lockdown on 23 March, 2020(News). On 4 April 2020, 3 new cases were tested positive making total count 9. It was on 4 April 2020 when the first local transmission was reported and following this Nepal entered the second stage of COVID 19 outbreak (MOHP). On 6 April 2020 the Government of Nepal extended the national lockdown until 15 April to contain the spread of the COVID 19.

Online survey was done in this study as the country was in the state of national lockdown during the study period so it was not feasible to do a community-based national sampling survey during this special period. Based on our results, we also intend to suggest concerned government authorities, NGOs, INGOs and other volunteer organizations to act accordingly to prevent the spread and contain the disease COVID 19.

People's adherence to control measures are essential, which is largely affected by their knowledge, attitudes, and practices (KAP) towards COVID-19 in accordance with KAP theory. Lessons learned from the past is that knowledge and attitudes towards infectious diseases are associated with levels of panic emotion among the population, which can further complicate attempts to prevent the spread of the disease..$^{5-8}$

\section{MATERIALS AND METHODS}

This cross-sectional survey was conducted from $4^{\text {th }}$ of April 2020 to $9^{\text {th }}$ of April 2020. Online survey was done in this study as the country was in the state of national lockdown during the study period so it was not feasible to do a community-based national sampling survey. Preformed online questionnaires were sent via email, Facebook, Whatsapp, Twitter. Nepalese residents were included in the study. The Ethics Committee of National Medical College approved our study protocol and procedures before the formal survey.

\section{Measures}

The questionnaire consisted of two parts: Demographics and KAP. Demographic variables included age, sex, occupation, and province of current residence. These online questionnaires contained a total of 29 questions among which 15 assessed Knowledge, 6 assessed attitude and remaining 8 assessed practice

\section{Statistical analysis}

Microsoft excel was used for data entry and IBM SPSS 21.0 software was used for the analysis of data. Descriptive statistics was calculated to describe the characteristics of the sample and cross-tabulation for the distribution of knowledge, attitude and practices of the participants towards COVID - 19. To examine the association of gender and medical background of the participants with 
their practices, binary logistic regression was done to calculate odds ratio with $95 \%$ confidence interval and $\mathrm{p}=0.05$.

\section{RESULTS}

A total of 760 participants completed the survey questionnaire. Among this final sample, 739 (97.2\%) were above the age of $18,499(65.7 \%)$ were men, $382(50.3 \%)$ held a medical degree or and $302(39.75 \%)$ were from Province 2. Other demographic characteristics are shown in Table 1.

The correct answer range of the questions on the COVID-19 knowledge questionnaire were 60.0-98.7\%. Correct answer range among Male participants was 59.7-98.8\% and among Female participants was 60.598.4\%. Among medical degree holders the correct

\begin{tabular}{lcc}
$\begin{array}{l}\text { Table 1: Demographic characteristics of the } \\
\text { participants }\end{array}$ & Frequency (n=760) & Percentage \\
\hline Variables & & \\
\hline Age & 739 & $97.2 \%$ \\
Above 18 & 21 & $2.8 \%$ \\
Below 18 & & \\
Gender & 499 & $65.7 \%$ \\
Male & 261 & $34.3 \%$ \\
Female & & \\
Occupation & 382 & $50.3 \%$ \\
Medical & 378 & $49.7 \%$ \\
Non-medical & & \\
Area of residence & 89 & $11.7 \%$ \\
Province 1 & 302 & $39.7 \%$ \\
Province 2 & 82 & $10.8 \%$ \\
Province 5 & 205 & $27.0 \%$ \\
Bagmati Province & 38 & $5.0 \%$ \\
Gandaki province & 11 & $1.4 \%$ \\
Karnali Province & 33 & $4.3 \%$ \\
Sudurpaschim province & & \\
\hline
\end{tabular}

answer range was 64.9-99.5\%. Among non-medical participants this ranged between $55-98.1 \%$. Virus as a cause of COVID 19 was the question with highest correct answers and risk of infection by eating or contacting domestic animals was the question with least correct answers (Table 2).

There was a total of 6 questions to assess attitude. Overall, $78.4 \%$ of participants were confident that COVID 19 can be successfully controlled. Male were more confident than female and medical degree holders more confident than non-medicos. In our study $90.3 \%$ of participants had agreed that drinking alcohol will not cure COVID 19. $77.9 \%$ were convinced that Nepal can win the battle against COVID 19. Almost all of the respondents $(96.1 \%)$ believed that selfprotection is necessary for the protection of others. 667(87.8\%) opined that not everyone with COVID 19 will die. Almost all participants 733 (96.4\%) believed that Lockdown is an effective measure to control the transmission(Table 3).

There was a total of 8 questions to access practice among the participants. Overall, $94.9 \%$ of the participants had not been too crowded places in recent days, 78.3\% people disposed of masks when it became moist or at least wearing for 8 hours, $88.2 \%$ were wearing masks in a correct way. Among participants $93.7 \%$ followed WHO hand washing technique. Overall, $94.7 \%$ of participants practiced social distancing and $95.0 \%$ followed lockdown (Table 4).

Practices like wearing a mask while leaving home, disposing of the mask when it becomes moist or at least 8 hours after wearing and following WHO hand washing technique were significantly better among participants with a medical degree(Table 5).

\section{Table 2: Knowledge of the participants on COVID 19 according to the gender and medical training}

\begin{tabular}{|c|c|c|c|c|c|}
\hline Knowledge & $\begin{array}{c}\text { Male } \\
(n=499)\end{array}$ & $\begin{array}{l}\text { Female } \\
(n=261)\end{array}$ & $\begin{array}{l}\text { Medical } \\
(n=382)\end{array}$ & $\begin{array}{l}\text { Non-medical } \\
\quad(n=378)\end{array}$ & $\begin{array}{c}\text { Total } \\
(n=760)\end{array}$ \\
\hline Virus as the cause of COVID 19 & $476(95.4 \%)$ & $249(95.4 \%)$ & $380(99.5 \%)$ & $345(91.3 \%)$ & $725(95.4 \%)$ \\
\hline Symptoms of COVID 19 & $383(76.8 \%)$ & $204(78.2 \%)$ & $328(85.9 \%)$ & $259(68.5 \%)$ & $587(77.2 \%)$ \\
\hline Who should get tested? & $424(85.0 \%)$ & $229(87.7 \%)$ & $350(91.6 \%)$ & $303(80.2 \%)$ & $653(85.9 \%)$ \\
\hline Mode of transmission & $453(90.8 \%)$ & $233(89.3 \%)$ & $360(94.2 \%)$ & $326(86.2 \%)$ & $686(90.3 \%)$ \\
\hline Protection from the spread of COVID 19 & $467(93.6 \%)$ & $245(93.9 \%)$ & $370(96.9 \%)$ & $342(90.5 \%)$ & $712(93.7 \%)$ \\
\hline Protection measures if recently visited to the area of high risk & $420(84.2 \%)$ & $216(82.8 \%)$ & $333(97.2 \%)$ & $303(80.2 \%)$ & $636(83.7 \%)$ \\
\hline Cure for COVID 19 & $462(92.6 \%)$ & $240(92.0 \%)$ & $375(98.2 \%)$ & $327(86.5 \%)$ & $702(92.4 \%)$ \\
\hline Infection by eating or contacting domestic animals & $298(59.7 \%)$ & $158(60.5 \%)$ & $248(64.9 \%)$ & $208(55.0 \%)$ & $456(60.0 \%)$ \\
\hline Transmission without fever & $401(80.4 \%)$ & $215(82.4 \%)$ & $333(87.2 \%)$ & $283(74.9 \%)$ & $616(81.1 \%)$ \\
\hline Infection through respiratory droplets & $447(89.6 \%)$ & $231(88.5 \%)$ & $366(95.8 \%)$ & $312(82.5 \%)$ & $678(89.2 \%)$ \\
\hline Wearing surgical mask as precaution & $370(74.1 \%)$ & $182(69.7 \%)$ & $274(71.7 \%)$ & $278(73.5 \%)$ & $562(72.6 \%)$ \\
\hline Preventive measures for children and young a & $423(84.8 \%)$ & $226(86.6 \%)$ & $337(88.2 \%)$ & $312(82.5 \%)$ & $649(85.4 \%)$ \\
\hline Avoid going to crowded places & $474(97.1 \%)$ & $252(98.4 \%)$ & $372(97.9 \%)$ & $354(97.3 \%)$ & $726(97.6 \%)$ \\
\hline $\begin{array}{l}\text { Isolation and treatment of infected person as effective way } \\
\text { to reduce the spread of the virus }\end{array}$ & $467(96.7 \%)$ & $127(95.7 \%)$ & $381(96.9 \%)$ & $345(95.8 \%)$ & $714(96.4 \%)$ \\
\hline Isolation of contact for the period of 14 days & $482(98.8 \%)$ & $249(98.4 \%)$ & $376(99.2 \%)$ & $355(98.1 \%)$ & $731(98.7 \%)$ \\
\hline
\end{tabular}


Table 3: Attitude of the participants towards COVID 19 according to the gender and medical training

\begin{tabular}{|c|c|c|c|c|c|}
\hline Variables & Male $(n=499)$ & Female $(n=261)$ & Medical ( $n=382)$ & $\begin{array}{l}\text { Non-medical } \\
(n=378)\end{array}$ & Total $(n=760)$ \\
\hline $\begin{array}{l}\text { COVID-19 can finally be successfully } \\
\text { controlled }\end{array}$ & $403(80.8 \%)$ & $193(73.9 \%)$ & $313(81.9 \%)$ & $283(74.9 \%)$ & $596(78.4 \%)$ \\
\hline Drinking alcohol will not cure COVID-19 & $453(90.8 \%)$ & $233(89.3 \%)$ & $356(93.2 \%)$ & $330(87.3 \%)$ & $686(90.3 \%)$ \\
\hline Nepal can win the battle against COVID-19 & $400(80.2 \%)$ & $190(72.8 \%)$ & $303(79.3 \%)$ & $287(75.9 \%)$ & $590(77.9 \%)$ \\
\hline $\begin{array}{l}\text { Self protection necessary for the protection } \\
\text { of others }\end{array}$ & $478(95.8 \%)$ & $252(96.6 \%)$ & $374(97.9 \%)$ & $356(94.2 \%)$ & $730(96.1 \%)$ \\
\hline Not everyone with COVID-19 will die & $430(86.2 \%)$ & $237(90.8 \%)$ & $359(94.0 \%)$ & $308(81.5 \%)$ & $667(87.8 \%)$ \\
\hline $\begin{array}{l}\text { Lockdown effective measure to control the } \\
\text { transmission }\end{array}$ & $481(96.4 \%)$ & $252(96.6 \%)$ & $376(98.4 \%)$ & $357(94.4 \%)$ & $733(96.4 \%)$ \\
\hline
\end{tabular}

Table 4: Practice of the participants against COVID 19 according to the gender and medical training

\begin{tabular}{|c|c|c|c|c|c|}
\hline Variables & $\begin{array}{c}\text { Male } \\
(n=499)\end{array}$ & $\begin{array}{l}\text { Female } \\
(\mathrm{n}=261)\end{array}$ & $\begin{array}{l}\text { Medical } \\
(n=382)\end{array}$ & $\begin{array}{l}\text { Non-medical } \\
(n=378)\end{array}$ & $\begin{array}{c}\text { Total } \\
(n=760)\end{array}$ \\
\hline Not been to crowded place in recent days & $471(94.4 \%)$ & $250(95.8 \%)$ & $365(95.5 \%)$ & $356(94.2 \%)$ & $721(94.9 \%)$ \\
\hline Worn mask while leaving home & $452(90.6 \%)$ & $234(89.7 \%)$ & $357(93.5 \%)$ & $329(87.0 \%)$ & $686(90.3 \%)$ \\
\hline Following WHO hand-washing technique & $465(93.2 \%)$ & $247(94.6 \%)$ & $369(96.6 \%)$ & $343(90.7 \%)$ & $712(93.7 \%)$ \\
\hline $\begin{array}{l}\text { Disposing of mask when it becomes moist or at least } 8 \\
\text { hours after wearing }\end{array}$ & $389(78.0 \%)$ & $205(78.5 \%)$ & $322(84.3 \%)$ & $272(72.0 \%)$ & $594(78.2 \%)$ \\
\hline Wearing mask in a correct way & $446(89.4 \%)$ & $224(85.8 \%)$ & 348 (91.1\%) & $322(85.2 \%)$ & $670(88.2 \%)$ \\
\hline Practicing social distancing & $477(95.6 \%)$ & $243(93.1 \%)$ & $366(95.8 \%)$ & $354(93.7 \%)$ & $720(94.7 \%)$ \\
\hline Following lockdown & $475(95.2 \%)$ & 247 (94.6\%) & $369(96.6 \%)$ & $353(93.4 \%)$ & $722(95.0 \%)$ \\
\hline
\end{tabular}

\begin{tabular}{|c|c|c|}
\hline Variables & OR $(95 \% \mathrm{Cl})$ & $P$ value \\
\hline \multicolumn{3}{|l|}{ Not going to crowded places } \\
\hline $\begin{array}{l}\text { Occupation (medical vs. } \\
\text { non-medical) }\end{array}$ & $0.78(0.40-1.50)$ & 0.462 \\
\hline $\begin{array}{l}\text { Gender (female vs. male } \\
\text { Wearing mask while leaving } \\
\text { home }\end{array}$ & $0.77(0.37-1.59)$ & 0.479 \\
\hline $\begin{array}{l}\text { Occupation (medical vs. } \\
\text { non-medical) }\end{array}$ & $2.20(1.32-3.67)$ & 0.002 \\
\hline Gender (female vs. male & $0.79(0.47-1.31)$ & 0.370 \\
\hline \multicolumn{3}{|l|}{$\begin{array}{l}\text { Following WHO hand- } \\
\text { washing technique }\end{array}$} \\
\hline $\begin{array}{l}\text { Occupation (medical vs. } \\
\text { non-medical) }\end{array}$ & $2.85(1.47-5.52)$ & 0.002 \\
\hline Gender (female vs. male & $1.09(0.57-2.11)$ & 0.779 \\
\hline \multicolumn{3}{|l|}{$\begin{array}{l}\text { Disposing of mask when it } \\
\text { becomes moist or at least } 8 \\
\text { hours after wearing }\end{array}$} \\
\hline $\begin{array}{l}\text { Occupation (medical vs. } \\
\text { non-medical) }\end{array}$ & $2.11(1.47-3.03)$ & $<0.001$ \\
\hline $\begin{array}{l}\text { Gender (female vs. male } \\
\text { Practicing social distancing }\end{array}$ & $0.91(0.631-1.32)$ & 0.643 \\
\hline $\begin{array}{l}\text { Occupation (medical vs. } \\
\text { non-medical) }\end{array}$ & $1.69(8.76-3.27)$ & 0.117 \\
\hline Gender (female vs. male & $0.57(0.29-1.09)$ & 0.092 \\
\hline
\end{tabular}

\section{DISCUSSION}

To the best of our knowledge our study is the first study in Nepal investigating the KAP towards COVID-19 among Nepalese residents. We studied the characteristics of KAP towards COVID 19 and identified associated demographic factors which can be useful for policy makers for prevention of COVID 19 and educating about it. Overall, 60.0 to $98.7 \%$ of the participants answered knowledge questions correctly. This finding was in accordance with a similar study done in China where the range of correct answers for knowledge questionnaires was 70.2 to $98.6 \%$. The level of awareness of SARS among Qataris was poor $(31.7 \%)$ compared to that among non-Qataris $(68.3 \%){ }^{10}$ A satisfactory correct rate of COVID-19 knowledge in Nepalese residents is probably because this study was done when COVID 19 had already become a global health problem and had started to show its effects in Nepal. People would gather information on COVID 19 from television, radio,internet, ring tones on all mobile phone service providers, discussion among peer groups etc. The range of correct answers to Knowledge questions among participants in our study 64.9-99.5\% was better than those of non-medical groups $55.0-98.1 \%$. This is probably due to better medical knowledge among participants with a medical degree.

Overall, $78 \%$ of participants were confident that COVID 19 can be successfully controlled. $77.9 \%$ were confident that Nepal can win the battle against COVID 19. Among participants of similar study in China 90.8\% were confident about control of COVID 19 and $97.1 \%$ of participants believed China would win the battle against the disease.' Better attitude among the participants of China is probably because health care facilities in China is comparatively better than Nepal. Second reason may be the better economic status of the country. 
Participants of our study had optimistic attitudes towards COVID-19. Most of them took precautions to prevent infection by COVID-19: not going to crowded places and wearing masks when leaving home. These preventive practices could be primarily attributed to the very strict prevention and control measures implemented by the government such as banning public gatherings. Secondly, they also could be the result of strict lockdown implemented by the Government of Nepal with provision of punishment to defaulters. Third, they also could be the result of the residents' good knowledge regarding the high infectivity of the COVID-19 virus, which can be easily transmitted between people via invisible respiratory droplets. Unfortunately, the present study still showed that $5.1 \%$ (4.5\% among medico's vs $5.8 \%$ non-medicos) residents went to crowded places and $9.7 \%$ (6.5\%among medico's vs $13.0 \%$ among non-medicos) did not wear masks when leaving homes. Unfortunately, 6.3\% (4.4\% among medico's vs $9.3 \%$ among non-medicos) of participants did not follow WHO hand washing techniques. The statistically significant differences in these practices between participants with a medical degree and those without it can be attributed to differences in knowledge about COVID 19. Similar findings were obtained among participants of medical and non-medical study group in a study done in Vietnam on KAP towards dengue fever. ${ }^{11}$

Due to limited availability of Internet access in Nepal we could not involve a large population. The vulnerable populations of Nepalese society under the COVID-19 epidemic such as older adults, population with co morbidities and people living in villages of Nepal had limited participation. These groups need special research attention in today's Nepal. Another limitation to study was lack of in-depth assessment of KAP towards the COVID-19 which would have been possible with interviews and group discussion. More than half of the participants hold a medical degree therefore the outcome of the study would not be a perfect representation of the general population.

\section{CONCLUSION}

To the best of our knowledge the present study is first of its kind in Nepal. Nepal is facing a stiff challenge to control the spread of COVID 19 among its population. Findings of this study show that knowledge among people of Nepal about COVID 19 is satisfactory. Yet a significant number of participants are lacking confidence when compared to other countries. A fraction of participants are lacking safety practices like not going to crowded places, wearingmasks, hand washing with WHO technique, strictly following lockdown while which can be dangerous in the view of spread of disease. All the concerned bodies need to focus on these aspects to win the battle against COVID 19.

\section{Limitations of the study}

Our study lacks complete representativeness due to its online nature thus more studies are warranted to investigate the KAP towards COVID-19 among Nepalese residents.

\section{ACKNOWLEDGMENTS}

The authors gratefully acknowledge all the participants.

\section{REFERENCES}

1. Huang C, Wang Y, Li X, Ren L, Zhao J, Hu Y, et al. Clinical features of patients infected with 2019 novel corona virus in Wuhan, China. Lancet 2020;395(10223):497-506.

https://doi.org/10.1016/S0140-6736(20)30183-5

2. Wu Z and McGoogan JM. Characteristics of and Important Lessons from the Corona virus Disease 2019 (COVID-19) Outbreak in China: Summary of a Report of 72314 Cases From the Chinese Center for Disease Control and Prevention. JAMA 2020; 323(13): 1239-1242.

https://doi.org/10.1001/jama.2020.2648

3. Munster VJ, Koopmans M, van Doremalen N, van Riel D and de Wit E. A Novel Corona virus Emerging in China - Key Questions for Impact Assessment. N Engl J Med 2020; 382:692-694. https://doi.org/10.1056/NEJMp2000929

4. World Health Organization. 2019-nCoV outbreak is an emergency of international concern. 2020.

http://www.euro.who.int/en/health-topics/emergencies/pages/ news/news/2020/01/2019-ncov-outbreak-is-an-emergency-ofinternational-concern.

5. Ajilore K, Atakiti I and Onyenankey K. College students' knowledge, attitudes and adherence to public service announcements on Ebola in Nigeria: Suggestions for improving future Ebola prevention education programmes. Health Education Journal 2017;76:648-660.

https://doi.org/10.1177/0017896917710969

6. Tachfouti N, Slama K, Berraho M and Nejjari C. The impact of knowledge and attitudes on adherence to tuberculosis treatment: a case-control study in a Moroccan region. Pan Afr Med J 2012; 12:52.

7. Person B, Sy F, Holton K, Govert B and Liang A. National Center for Inectious Diseases SCOT. Fear and stigma: the epidemic within the SARS outbreak. Emerg Infect Dis 2004; 10:358-363.

https://doi.org/10.3201/eid1002.030750

8. Tao N. An analysis on reasons of SARS-induced psychological panic among students. Journal of Anhui Institute of Education 2003; 21:78-79.

9. Zhong BL, Luo W, Li HM, Zhang QQ, Liu XG, Li WT, et al. Knowledge, attitudes, and practices towards COVID-19 among Chinese residents during the rapid rise period of the COVID-19 outbreak: a quick online cross-sectional survey. Int J Biol Sci 
2020; 16(10):1745-1752.

https://doi.org/10.7150/ijbs.45221

10. Bener A and Al-Khal A. Knowledge, attitude and practice towards SARS. J R Soc Promot Health 2004; 124(4):167-170.

https://doi.org/10.1177/146642400412400408
11. Ky Truong TN, Vo TQ, Nguyen NH, Nhat Nguyen QP, Nguyen PL and Hoang Nguyen TL. Knowledge, attitudes, and practices among university students in relation to dengue fever: A multicenter study across Vietnamese regions. J Pak Med Assoc 2019; 69 (Suppl 2) (6):S95-S107.

\section{Authors Contribution:}

HA- Concept and design of the Study, reviewed the literature, manuscript preparation and critical revision of the manuscript; TG- Statistically analyzed and interpreted, critical revision of manuscript; BMS- Data collection and review of literature; RR- Concept of study and data collection; RPT- Conceptualized study, Statistical analysis and interpretation.

\section{Work attributed to:}

Department of Internal Medicine National Medical College Birgunj, Nepal.

Orcid ID:

Dr. Asraf Hussain - (1) http://orcid.org/0000-0001-6218-05002

Source of Support: None, Conflicts of Interest: None. 